\title{
Contagious Asian Crisis: Bank Lending and Capital Inflows
}

\author{
Saleheen Khan \\ Minnesota State University
}

\begin{abstract}
This paper presents empirical evidence that bank lending, and capital inflows can explain the severity of the Asian crisis of 1997 above and beyond macroeconomic fundamentals. We find that countries that share Japanese banks as their major lender with Thailand, the first victim in the Asian crisis, tend to experience currency crisis. We also find evidence that link short-term capital inflows to the severity of the Asian crisis.
\end{abstract}

- JEL Classification: F30, F31, F32, F34

- Key words: exchange rate, currency crisis, and capital inflows

\section{Introduction}

The recent Asian crisis of 1997 has once again raised the question of contagion effects. An appreciating real exchange rate and current account deficit, as well as financial sector problems due to excessive risky lending, which caused inflation in assets prices in boom time and collapsed in later times, may be traced to the cause of currency crisis in Thailand, the first victim in the Asian crisis. On July 2, 1997, the Thai authorities were forced to abandon the dollar exchange rate peg, subsequently, crises spread to all of East Asia. How this crisis spread so rapidly from the first victim to the other East Asian economies has caught the attention of a growing number of economists in recent times. This paper examines the role of the international bank lending and short-term capital inflow in the propagation of

*Corresponding address: Saleheen Khan, Department of Economics Minnesota State University 121 Morris Hall Mankato, MN 56001, Tel: (507) 389 2711, Fax: (507) 389 6377, E-mail: saleheen.khan@ mnsu.edu (C2004-Center for International Economics, Sejong Institution, All Rights Reserved. 
the East Asian crisis.

The paper investigates two financial channels, bank lending and capital inflows to explain the severity of the Asian crisis. First, crises can spread across countries through international bank lending. An offshore bank may lend to many countries. If any of those countries, especially a major borrower, is hit by financial crisis, it will affect the banks balance sheet. The bank needs to rebalance its portfolio, which may require credit contraction to other countries, and that might result in financial crises in those countries. We find evidence that propagation of the Asian crisis can be explained through the bank-lending channel.

Second, excessive capital inflows lead to a currency crisis eventually. However, the composition of flows matter for various reasons. Long-term capital inflows such as foreign direct investment are beneficial, because they increase the productive capacity of the country and they are less volatile as well. On the other hand, short-term capital inflows are very volatile and are associated with consumption boom or inefficient investment, thus weaken countries fundamentals and bring balance of payment crisis eventually. We argue in this paper that shortterm capital inflows, not long-term capital inflows such as FDI, could be a channel to the propagation of the Asian crisis.

The paper is organized as follows: Section II gives a brief survey of literature on capital inflows, and international bank lending as possible channels to explain the severity of the Asian crisis; Section III provides our methodology, followed by our main empirical results in Section IV; and Section V concludes the paper.

\section{Literature}

\section{A. Common Bank Lending}

An international bank may be exposed to many countries through its loan portfolio. If a crisis hits any one of those countries, especially a major borrower, then the bank needs to rebalance its portfolio following the losses in the ground zero country, ${ }^{1}$ which may require credit contraction in other countries in which they hold positions. Not only may banks be unwilling to extend new credits to other borrowers, but they may also refuse to roll over existing short-term loans; this policy will lead to capital outflows from those countries. A large-scale capital outflow runs down their international reserves, and thus creates financial crises in

${ }^{1}$ See Agenor and Aizenman (1998). 
those countries.

Kaminsky and Reinhart (2000) test the significance of common bank lending channel in propagation of currency crisis. They use the "signals" approach to assess the probability of a contagion currency crisis. ${ }^{2}$ They formed clusters of countries based on a bank lending channel, a liquidity channel, and a trade channel and show that these clusters tend to be regional. ${ }^{3}$ They find two bank lending clusters in their sample, namely the Japanese bank cluster, comprises Indonesia, Malaysia, and Thailand and the US bank cluster, includes Argentina, Brazil, Chile, Colombia, Mexico, the Philippines, Uruguay, and Venezuela. They show that the probability of a crisis in Indonesia, Malaysia, and Thailand, conditional on the knowledge that one or two of these countries already had a crisis, tends to be higher than the unconditional probability of a crisis. Similar results were found in the Latin American countries. The probability of a crisis in a Latin American country increases with the knowledge that one or more other Latin countries already having a currency crisis.

Van Rijckeghem and Weder (1999) test the bank lending in transmitting currency crisis using a panel data on capital flows to 30 emerging markets. They developed a Fund composition index which measures the intensity of competition of bank funds between ground zero and another country in the sample analog to the trade competition in the third market by Glick and Rose (1999). They find that the degree to which countries compete for funds from the common bank lender is a fairly robust predictor of the incidence of the contagion currency crises.

Even though we also test the significance of the common bank-lending channel in transmitting currency crises from the first victim to other emerging markets, we differ from Kaminsky and Reinhart (2000) and Van Rijckeghem and Weder (1999) in approach and methodology.

\section{B. Capital Inflows}

Capital inflows to emerging markets have been sustained at a relatively high level throughout the 1990s even though a slight decline is observed after the Mexican Peso crisis of 1994. Even though capital inflows can increase welfare by consumption smoothing and may also increase the productive capacity of a

\footnotetext{
${ }^{2}$ The "Signal" approach is described in more details in Kaminsky and Reinhart (1999), Kaminsky, Lizondo, and Reinhart (1998), and Kaminsky (1998).

${ }^{3}$ This may explain the regional nature of contagion currency crises. Glick and Rose (1999) find that trade channel is useful to explain the propagation of a crisis.
} 
country, it has bitter consequences as well. Excessive capital inflows can also have less desirable macroeconomic effects, such as rapid monetary expansion, inflationary pressure, real exchange rate appreciation, and widening current account deficits, which may eventually leads to a currency crisis.

Calvo, Leiderman, and Reinhart (1996) point out few causes to capital inflows in emerging markets. Firstly, lower interest rates in the developed nations attracted investors to Asia and Latin American economies where interest rates were relatively higher. Second, the early 1990s recessions in the United States, Japan, and many countries of Europe made profit opportunities in developing countries appear relatively more attractive. Third, there has been a trend toward international diversification of investment. Fourth, several emerging market economies adopt policies that liberalize the capital and financial markets. Finally, a large capital inflow to one or two large countries in a region may generate externalities for the smaller neighboring countries.

Chuhan, Claessens, and Mamingi (1993) find, using monthly bond and equity flows from the U.S. to nine Latin American countries, that bond flows respond strongly to the countries credit rating, while price-earning ratios were uniformly unimportant. On the other hand, the US interest rate was important for both bond and equity flows. ${ }^{4}$ The World Bank (1997) has suggested that idiosyncratic country factors may have played a much larger role in recent years inflow episodes to the emerging markets.

Even though large capital inflows eventually cause a currency crisis, it is the short term capital inflows, rather than long term capital inflows, is the main culprit in the episodes of contagion currency crises. Sach, Tornell, and Velasco (1999) cannot find evidence supporting the hypothesis that high capital inflows (which contains FDI flows and long maturity bonds and loans) make a currency crisis more severe, however they find that short term capital inflows does seem to matter in explaining propagation of the Mexican currency crisis.

\section{Methodology}

Our objective for this paper is to determine the effect of common bank lender, and the accumulation of short-term capital inflows to explain the severity of the Asian crisis of 1997-98. Our interest is not to determine how and when the Asian

${ }^{4}$ More systematic evidence supporting a role for domestic factors in attracting capital inflows was provided in Hernandez and Rudolf (1994) 
crisis originated from, Thailand, the first victim, rather how the crisis spread across other emerging markets in Asia.

We run the benchmark regression of the form:

$$
\text { Cirsis }_{i}=\alpha_{0}+\beta \text { Macro }- \text { Controls }_{i}+\varphi \text { Banklending }+\varepsilon
$$

Where we measured bank lending as a dummy variable, by assigning the value of 1 to those countries in our sample, which like Thailand, share Japanese banks as their major lender. Our objective is to investigate whether countries that share Japanese banks as their major lender suffer more than other countries in the sample. We use the Bank for International Settlements semi-annual consolidated data for June 1997. 5,6 The data include international claims of affiliates and branches which have their head-offices outside the BIS reporting area. We also computed two different perturbations of our benchmark measure, and find that common bank lending measures are robust to the exact way we compute them. The first is a continuous measure that calculates percentage share of total lending from the Japanese banks. The second measure calculates the intensity of competition for funds from the Japanese banks. This variable is calculated in the similar fashion as the trade competition in the third market is calculated in Glick and Rose(1999). The Fund Competition from Japanese Banks (FCJB) is calculated as follows:

$$
\begin{aligned}
& \text { FCJB }_{j}(\text { share }) \equiv \\
& \qquad\left\{\left[\left(b_{0 j}+b_{i j}\right) /\left(b_{0}+b_{i}\right)\right] \bullet\left\lfloor 1-\left|\left(b_{i j} / b_{i}-b_{0 j} / b_{0}\right)\right| /\left(b_{i j} / b_{i}+b_{0 j} / b_{0}\right)\right]\right\}
\end{aligned}
$$

Where 0 stands for ground zero (first victim) country and $\mathrm{j}$ stands for a common lender (Japanese Banks). Here we consider Japanese banks as the common lender. Ground zero (Thailand) and country i compete for funds from Japanese banks. $b_{i j}$ represents country is borrowing from Japanese banks. $b_{i}$ denotes total amount of funds country i's borrow from the world banking system. The first component of the equation is a measure of overall importance of Japanese banks to country $i$ and 0 . The second component captures the extent to which country $i$ and the first victim compete for funds from the Japanese banks.

Here, Crisis $_{i}$ is a continuous measure of exchange market pressure calculated as the weighted average of the percentage depreciation of nominal exchange rate

\footnotetext{
${ }^{5}$ Consolidated cross-border claims in all currencies and local claim in non-local currencies.
}

${ }^{6}$ We use the BIS Data for June 1997 to measure the borrowing position of every country in our sample on the eve of the Asian crisis of 1997. 
with respect to U.S. dollar and the percentage decline in foreign reserve for six months following the start of the crisis. ${ }^{7}$ The weights are determined so as to equalize the volatility of the components. We calculate the inverse of the variances for each variable with years of monthly data prior to the crisis. Then we compute weight for each variable as its inverse of variance over sum of the inverse of the variances. $^{8,9}$

\section{Does large capital inflows make currency crisis more severe?}

A popular view is that large capital inflows today may lead to outflows tomorrow, and thus lead to a currency crisis. However, we know short-term capital inflows are more volatile and a sudden reversal may lead to a currency crisis in a country. ${ }^{10}$ We like to investigate whether the effect of large short-term capital inflows can explain severity of a crisis above and beyond the effect of macrocontrols. The basic equation regresses the crisis index on the variable capital inflows (short term inflows or inflow series that contains both short term and long term inflows) taking account the state of the economic fundamentals and the adequacy of foreign reserves. We estimate our benchmark regressions of the following form using ordinary least squares:

$$
\text { Crisis }_{i}=\beta_{0}+\beta_{2}(\text { Inflows })+\beta_{4}\left(D^{L R} \times \text { Inflows }\right)+\beta_{6}\left(D^{L R} \times D^{W F} \times \text { Inflows }\right)+\varepsilon
$$

We classify, like Tornell (1999), a country has high reserves if its M2/ Reserves rate is below 1.8 , and a country has strong fundamentals if lending boom is negative and its real exchange rate appreciation is lower than $5 \%$. We create a dummy variable for weak fundamentals, such that we assign $D^{W F}$ equals to one if a country has weak fundamentals, and assign 0 for strong fundamentals. Similarly, we assign $D^{L R}$ equals to one if a country has low reserves and assign 0 for high reserves.

${ }^{7}$ The Asian crisis is measured from end of June 1997.

${ }^{8}$ Sachs, Tornell and Velasco (1996), Tornell (1999), and Eichengreen, Rose and Wyplosz (1996) calculated their crisis index in a similar fashion.

${ }^{9}$ Raising the interest rate may fend off speculative attack. So, it would be reasonable to incorporate percentage change in domestic interest rate in our crisis index, but lack of data on interest rates of emerging market economies limits us in doing so.

${ }^{10}$ World Bank (1997) investigation finds that quarterly volatility of FDI and portfolio flows for eight major capital recipient countries during the 1990s (measured by the coefficient of variation of series) yielded higher volatility estimates for portfolio flows in six of eight countries examined. 


\section{Macro control:}

A number of macroeconomic and financial variables can explain the severity of a crisis. Countries with macroeconomic and financial imbalances may face speculative attacks. The control variables that we employ in this study are drawn from a set of variables that have been shown to be relevant in explaining currency crises in the empirical literature. ${ }^{11}$ We use the following variables: lending boom, real exchange rate appreciation, current account balance as a percentage of GDP, the government budget as a percentage of GDP, and the level of M2 over international reserves. We are interested in determining whether bank lending channels, capital inflows, and change in market sentiment independent of macroeconomic imbalances can explain the severity of a crisis. The data are two cross-sections for 25 emerging market countries. The countries in the sample are: Argentina, Brazil, Mexico, Chile, Colombia, Peru, Venezuela, India, Indonesia, Korea, Malaysia, Pakistan, the Philippines, Sri Lanka, Thailand, Jordan, South Africa, Turkey, Zimbabwe, Poland, Czech Republic, Hungary, Singapore, China, and Taiwan. ${ }^{12}$ We use 1996 macro data for the Asian crisis. ${ }^{13}$

\section{Results}

Equation 1 of Table 1, reports the results of regressing the crisis index on the macro control variables and the common bank-lending dummy. Bank lending dummy is significant at the $1 \%$ level. Its coefficient (10.758) suggest that the severity of the crisis increases by around 11 additional percentage point in countries that share the Japanese banks as their major lender like the first victim, Thailand. Among the macro-control variables, the current account is significant. The current account is significant at the $1 \%$ level and has the correct sign. Current account deficits tend to increase the severity of a crisis. Equation 2 and Equation 3 leaves macro-controls unchanged and substitute two different continuous measures of

\footnotetext{
${ }^{11}$ See Kaminsky, Lizondo, and Reinhart (1998), which gives a survey of 28 empirical papers. The variables Lending Boom, percentage change in real exchange rates, and M2 over international reserves have been emphasized in explaining the variation of nominal exchange rate in most of the recent literature; see Sachs, Tornell and Velasco (1996), Tornell (1999), Grier and Grier (2001), and Corsetti, Passenti and Roubini (1998).

${ }^{12}$ Lack of availability of Macro and Financial Control Variables for many emerging market countries limits our sample size.

${ }^{13}$ See Appendix B for detailed discussion of our data set.
} 
Table 1. Coefficients and absolute t-statistics of multivariate OLS estimates. Dependent variable: Crisis index: six month horizon

\begin{tabular}{|c|c|c|c|}
\hline \multicolumn{4}{|c|}{ Asian Crisis 1997-1998. } \\
\hline Variable & Eq. 1 & Eq. 2 & Eq. 3 \\
\hline \multirow[t]{2}{*}{ Constant } & 2.471 & 1.1 & .745 \\
\hline & $(1.295)$ & $(.417)$ & $(.245)$ \\
\hline \multirow[t]{2}{*}{ Lending Boom } & .006 & -.001 & .024 \\
\hline & $(.264)$ & $(.006)$ & $(1.402)$ \\
\hline Real & .103 & .109 & .161 \\
\hline Appreciation & $(.406)$ & $(.418)$ & $(.642)$ \\
\hline Current & -.758 & -.680 & -.573 \\
\hline Account & $(2.935)^{* *}$ & $(2.720)^{* *}$ & $(2.311)$ \\
\hline \multirow[t]{2}{*}{ M2/Reserve } & -.027 & -.055 & .064 \\
\hline & $(.474)$ & $(.950)$ & (1.138) \\
\hline \multirow[t]{2}{*}{ Budget } & .134 & .106 & .156 \\
\hline & $(.289)$ & $(.256)$ & $(.371)$ \\
\hline Lending & 10.758 & -------- & -------- \\
\hline Dummy & $(2.384)^{* *}$ & & \\
\hline Lending Share & & .359 & -------- \\
\hline (Japanese Bank) & ------- & $(2.296)^{* *}$ & \\
\hline Fund Competition & & & 3.61 \\
\hline (Japanese Bank) & -------- & -------- & $(2.375)^{* *}$ \\
\hline $\mathrm{R}^{2}$ & .311 & .374 & .261 \\
\hline
\end{tabular}

Heteroskedasticity consistent t-statistics are reported in parentheses.

(*) Indicates statistical significance at $10 \%$ level

(**) Indicates statistical significance at $5 \%$ or better.

common bank lending variables. In Equation 2 we use percentage share of borrowing from Japanese banks and in Equation 3 we use fund competition from Japanese banks. Both of these variables are significant at the $1 \%$ level. Our finding of a positive statistically significant role for common bank lending channel is robust to the variant measures of common bank lending variable.

Table 2 presents the same regressions as Table 1, but also controls for TMEC (Third Market Export Competition between Thailand and other countries in the sample). Common bank lending channel lost its significance in all three equations and $T M E C$ also turn out to be insignificant. There exist a high correlation between trade linkages and competition for funds. The historical expansion of bank lending started with financing trade. ${ }^{14}$ This high collinearity may be the reason behind the

\footnotetext{
${ }^{14}$ See Van Rijckeghem and Weder (1999) for details discussion of this issue.
} 
Table 2. Coefficients and absolute t-statistics of multivariate OLS estimates. Dependent variable: Crisis index: six month horizon.

\begin{tabular}{lccc}
\hline & \multicolumn{2}{c}{ Asian Crisis $1997-1998}$. & \\
\hline Variable & Eq. 1 & Eq. 2 & Eq. 3 \\
Constant & -1.928 & -4.295 & -4.765 \\
& $(.415)$ & $(1.074)$ & $(1.179)$ \\
Lending Boom & .003 & -.000 & 008 \\
& $(.122)$ & $(.004)$ & $(.309)$ \\
Real & .247 & .318 & .347 \\
Appreciation & $(.759)$ & $(.894)$ & $(1.003)$ \\
Current & -.643 & -.556 & -.510 \\
Account & $(2.134)^{* *}$ & $(1.997)^{*}$ & $(1.970)^{*}$ \\
M2/Reserve & -.054 & -.077 & -.082 \\
& $(.668)$ & $(1.023)$ & $(1.16)$ \\
Budget & .075 & .054 & .063 \\
& $(.158)$ & $(.123)$ & $(.143)$ \\
Lending & 6.586 & ------- & - \\
Dummy & $(.921)$ & & $-1 .------$ \\
Lending Share & & .141 & \\
(Japanese Bank) & ------- & $(.519)$ & $(.494)$ \\
Fund Competition & & .138 & \\
(Japanese Bank) & ------- & ------- & \\
TMEC & .102 & .148 & $(1.094)$ \\
$\mathrm{R}^{2}$ & $(.796)$ & .311 & \\
\hline
\end{tabular}

Heteroskedasticity consistent t-statistics are reported in parentheses.

(*) Indicates statistical significance at $10 \%$ level

(**) Indicates statistical significance at $5 \%$ or better.

insignificance of both TMEC and common bank lending channel when we include both variables in the same regression.

Equation 1 of Table 3 reports the results of regressing crisis index on capital inflows (a series that consist of short term and long term flows). We also interact capital inflows with dummy variable representing economic fundamentals and reserve adequacy. We would like to explore the view that excessive capital inflows must lead eventually to a currency crisis. To explore whether this view is supported by the data, we estimate this regression imposing two restrictions: $\beta_{6}+\beta_{7}=0$ and $\beta_{6}$ $+\beta_{7}+\beta_{8}=0$. The $\rho$ values for the above two null hypotheses are .598 and .016 respectively. Thus, we reject the null hypotheses. Therefore, we find evidence suggesting that high capital inflows make a currency crisis more severe when a 
Table 3. Coefficients and absolute t-statistics of multivariate OLS estimates. Dependent variable: Crisis index: six month horizon

\begin{tabular}{llcc}
\hline \multicolumn{3}{c}{ Asian Crisis 1997-1998. } \\
\hline Estimated Coefficient & \multicolumn{1}{c}{ Variable } & Eq. 1 & Eq. 2 \\
$\beta_{0}$ & Constant & 4.241 & 5.204 \\
& & $(1.602)$ & $(1.277)$ \\
$\beta_{1}$ & Lending Boom & .02 \\
& & & $(.562)$ \\
$\beta_{2}$ & Real Appreciation & & .207 \\
& & & $(.588)$ \\
$\beta_{3}$ & Current Account & & -.459 \\
& & & $(.515)$ \\
$\beta_{4}$ & M2/Reserve & & -.06 \\
& & & $(.443)$ \\
$\beta_{5}$ & Budget & & .357 \\
& & & $(.582)$ \\
$\beta_{6}$ & Capital Inflows & .156 & -.196 \\
& & $(.279)$ & $(.159)$ \\
$\beta_{7}$ & Capital Inflows $\times D^{L R}$ & -1.165 & .226 \\
& & $.620)$ & $(.099)$ \\
$\beta_{8}$ & Capital Inflows $\times D^{L R} \times D^{W F}$ & 2.550 & 1.605 \\
& & $(1.40)$ & $(.716)$ \\
Addendum: Wald tests & & $\rho$ values & $\rho$ values \\
Null Hypothesis & & & \\
$\beta_{6}+\beta_{7}=0$ & & .598 & .868 \\
$\beta_{6}+\beta_{7}+\beta_{8}=0$ & & .016 & .322 \\
$\mathrm{R}^{2}$ & & .287 & .356 \\
\hline
\end{tabular}

Heteroskedasticity consistent t-statistics are reported in parentheses.

(*) Indicates statistical significance at $10 \%$ level

(**) Indicates statistical significance at $5 \%$ or better.

country has weak fundamentals and low reserves. Equation 2 of Table 3 presents the estimates of a regression that includes capital inflows and macro-control. The $\rho$ values for the null hypotheses $\beta_{6}+\beta_{7}=0$ and $\beta_{6}+\beta_{7}+\beta_{8}=0$ are .322 and .356 respectively. Thus capital inflows cannot explain the severity of a currency crisis above and beyond the effect of macro-controls.

Similarly, Equation 1 of Table 4 presents the results of the regressing crisis index on short-term capital inflows. We reject the null hypothesis $\beta_{6}+\beta_{7}+\beta_{8}=0$ with a $\rho$ value of .048 . Therefore we may conclude that high short-term capital inflows make a currency crisis more severe when a country has weak fundamentals and low reserves. In Equation 2, we control for macroeconomic fundamentals. The null 
Table 4. Coefficients and absolute t-statistics of multivariate OLS estimates. Dependent variable: Crisis index: six month horizon.

\begin{tabular}{|c|c|c|c|}
\hline \multicolumn{4}{|c|}{ Asian Crisis 1997-1998. } \\
\hline Estimated Coefficient & Variable & Eq. 1 & Eq. 2 \\
\hline \multirow[t]{2}{*}{$\beta_{0}$} & Constant & 7.398 & 5.015 \\
\hline & & $(3.651)^{* *}$ & $(1.903)^{*}$ \\
\hline$\beta_{1}$ & Lending Boom & & .039 \\
\hline \multirow{2}{*}{$\beta_{2}$} & Real Appreciation & & $\begin{array}{c}(1.245) \\
.263\end{array}$ \\
\hline & & & $(.838)$ \\
\hline \multirow[t]{2}{*}{$\beta_{3}$} & Current Account & & -1.29 \\
\hline & & & $(2.717)^{* *}$ \\
\hline \multirow[t]{2}{*}{$\beta_{4}$} & M2/ Reserve & & -.092 \\
\hline & & & $(.816)$ \\
\hline \multirow[t]{2}{*}{$\beta_{5}$} & Budget & & .145 \\
\hline & & & $(.250)$ \\
\hline \multirow[t]{2}{*}{$\beta_{6}$} & Short term Inflows & -.238 & -1.355 \\
\hline & & $(.511)$ & $(1.854)$ \\
\hline \multirow[t]{2}{*}{$\beta_{7}$} & Short term Inflows $\times D^{L R}$ & -1.659 & -1.642 \\
\hline & & $(.562)$ & $(.565)$ \\
\hline \multirow[t]{2}{*}{$\beta_{8}$} & Short term Inflows $\times D^{L R} \times D^{W F}$ & 4.231 & 5.201 \\
\hline & & $(1.363)$ & $(1.83)$ \\
\hline Addendum: Wald tests & & $\rho$ values & $\rho$ values \\
\hline \multicolumn{4}{|l|}{ Null Hypothesis } \\
\hline \multicolumn{2}{|l|}{$\beta_{6}+\beta_{7}=0$} & .520 & .29 \\
\hline \multicolumn{2}{|l|}{$\beta_{6}+\beta_{7}+\beta_{8}=0$} & .048 & .06 \\
\hline \multicolumn{2}{|l|}{$\mathrm{R}^{2}$} & .195 & .529 \\
\hline
\end{tabular}

Heteroskedasticity consistent t-statistics are reported in parentheses.

(*) Indicates statistical significance at $10 \%$ level

$(* *)$ Indicates statistical significance at $5 \%$ or better.

hypothesis $\beta_{6}+\beta_{7}+\beta_{8}=0$ is still rejected with a $\rho$ value of .06. Thus, short-term capital inflows can have an extra effect to the propagation of a currency crisis above and beyond the effect of macroeconomic fundamentals. Table 5 presents the regression results that test for the effect of FDI (the most stable component of capital inflows) to explain the severity of a currency crisis. We cannot find any evidence that links FDI to the severity of currency crisis.

\section{Sensitivity Analysis:}

We test the robustness of the regression results presented in Table 1 through Table 5, by using different set of macro control variables and different measures of 
Table 5. Coefficients and absolute t-statistics of multivariate OLS estimates.

Dependent variable: Crisis index: six month horizon.

\begin{tabular}{llcc}
\hline \multicolumn{3}{c}{ Asian Crisis 1997-1998. } \\
\hline \multicolumn{1}{c}{ Estimated Coefficient } & \multicolumn{1}{c}{ Variable } & Eq. 1 & Eq. 2 \\
$\beta_{0}$ & Constant & 8.961 & 11.099 \\
& & $(2.433)^{* * *}$ & $(2.241)^{* *}$ \\
$\beta_{1}$ & Lending Boom & -.001 \\
& & & $(.043)$ \\
$\beta_{2}$ & Real Appreciation & .333 \\
& & & $(784)$ \\
$\beta_{3}$ & Current Account & & -.680 \\
& & & $(-1.339)$ \\
$\beta_{4}$ & M2/Reserve & & -.028 \\
& & & $(.208)$ \\
$\beta_{5}$ & Budget & & 1.115 \\
& & & $(1.619)$ \\
$\beta_{6}$ & FDI & .132 & .218 \\
& & $(.919)$ & $(.182)$ \\
$\beta_{7}$ & $F D I \times D^{L R}$ & -.14 & .057 \\
& & $(.567)$ & $(.182)$ \\
$\beta_{8}$ & $F D I \times D^{L R} \times D^{W F}$ & .387 & .012 \\
& & $(.888)$ & $(.022)$ \\
Addendum: Wald tests & & $\rho$ values & $\rho$ values \\
Null Hypothesis & & & \\
$\beta_{6}+\beta_{7}=0$ & & .80 & .653 \\
$\beta_{6}+\beta_{7}+\beta_{8}=0$ & & .283 & .768 \\
$\mathrm{R}^{2}$ & & .11 & .288 \\
\hline
\end{tabular}

Heteroskedasticity consistent t-statistics are reported in parentheses.

(*) Indicates statistical significance at $10 \%$ level

(**) Indicates statistical significance at $5 \%$ or better.

dependent variable. Our finding that common bank lending and short-term capital inflows can explain the severity of Asian crisis is in fact a robust result to the above tests.

\section{Conclusion}

The purpose of this paper is to investigate whether common bank lending and short-term capital inflows can explain the severity of the Asian crisis. We find that "common bank lender" channel was important in the propagation of the Asian crisis above and beyond the effect of macro-controls. Japanese banks were the 
major lender to Thailand, the first victim of the Asian crisis. After the Thai devaluation in 1997, the Japanese banks contracted their credits to the other Asian economies, and subsequently other Asian economies such as Indonesia, Malaysia, and South Korea experienced currency crises. Thus, the lending of Japanese banks seems to play a role in explaining the severity of the Asian crisis. We also computed two different perturbations of our benchmark measure, and find that common bank lending measures are robust to the exact way we compute them. However, links between common bank lending channel to severity of currency crisis disappear with the inclusion of trade link variable in the regression. Trade and bank lending are highly correlated. Thus, we cannot differentiate their effects when we regress them together.

We find that composition of capital inflows matters to explain the severity of a currency crisis. Short-term flows are very volatile and easily become outflow when the going gets tough. On the other hand, long-term flows such as FDI are relatively stable. We find evidence that short-term flows explain the severity of the Asian crisis, while no such evidence can be found for total capital-inflows. Both total capital inflows and short-term capital inflows increase the severity of the Asian currency crisis in countries with low reserves and weak fundamentals when macroeconomic fundamentals are not controlled for. However, only short-term capital inflows can explain the severity of a crisis above and beyond the effect of macroeconomic fundamentals. FDI, the most stable component of the capital inflows does not seem to have any effect in explaining the crisis even when country has weak fundamentals and low reserves.

Received 17 June, 2002, Accepted 23 December, 2002

\section{References}

Agenor P-R, and and Joshua Aizenman (1998), "Contagion and volatility credit markets," Staff Papers, International Monetary Fund, Vol. 45, pp 207-235.

Calvo, Guilermo, Leonardo Leiderman, Carmen M.Reinhart (1996), "Inflows of Capital to Developing Countries in the 1990s," The Journal of Economic Perspectives, Vol. 10, pp 123-139.

Chuhan, Punam, Stijn Claessens, and Nlandu Mamingi (1998), "Equity and Bond Flows toAsia and Latin America; The Role of Global and Country Factors." Journal of Development Economies, Vol. 55, pp 439-63

Corsetti, Giancarlo, Paolo Passenti, and Nouriel Roubini (1998), "Paper Tigers? A Model 
of the Asian Crisis," NBER working paper \# 6783.

Eichengreen, Barry, Andrew Rose, and Charles Wyplosz (1996), "Contagious Currency Crises," NBER working Paper No 5681.

Glick, Reuven and Andrew K. Rose (1999), "Contagion and Trade: Why are Currency Crises Regional," Journal of International Money and Finance, Vol. 18 pp. 603-617.

Grier, Kevin B. and Robin M. Grier (2001), “ Macroeconomic Indicators, Exchange Rate Regimes, Currency Depreciation and Stock Market Performance in the Crisis of 1997," Economic Inquiry, Vol. 39, pp 139-48.

Hernandez, Leonardo, and Heinz Rudolph (1994), "Domestic Factors, Sustainability, and Soft Landing in the New Wave of Capital Inflows, World Bank mimeo.

Kaminsky, Graciela, (1999) "Currency and Banking Crises: The Early Warning of Distress," Board of Governors of the Federal Reserve System, International Finance Discussion Paper 629.

Kaminsky, Graciela and Carmen Reinhart (1999),"The Twin Crises: The Causes of Banking and Balance of Payments Problem," American Economic Review, Vol. 89, pp. 473-500.

Kaminsky, Graciela and Carmen Reinhart (2000), "On Crises, Contagion, and Confusion," Journal of International Economics, Vol. 51, pp. 145-68.

Kaminsky, Graciela and Saul Lizondo, and Carmen M. Reinhart (1998), "Leading Indicators of Currency Crises," Staff Papers, International Monetary Fund, Vol. 45, pp. 1-48.

Radelet, Steven and Jeffery Sachs (1998), The Onset of East Asian Financial Crisis," NBER Working Paper No. 6680.

Sachs, Jeffrey, Aron Tornell, and Andres Velasco (1996), Financial Crises in Emerging Markets: The Lessons From 1995," Brookings Paper on Economic Activity, No. 16, pp. 147-215.

Tornell, Aron (1999), "Common Fundamentals in the Tequila and Asian Crises," NBER Working Paper No. 7139.

Van Rijckeghem, Caroline, and Beatrice Weder (1999), "Sources of Contagion: Finance or Trade," IMF Working Paper No. 146.

World Bank (1997), Private Capital Flows to Developing Countries: the Role to Financial Integration, Oxford University Press. 
Appendix A

Liabilities as percentage of borrower's total liabilities:( as of December '97)

\begin{tabular}{|l|c|c|}
\hline Borrower & Liabilities to Japan(\$bn) & Percentage \\
\hline Argentina & 1.6 & 3.6 \\
Brazil & 4.9 & 6.9 \\
Mexico & 4.9 & 7.4 \\
Chile & 1.3 & 7.6 \\
Colombia & 1.3 & 7.8 \\
Peru & .09 & 1.2 \\
Venezuela & .366 & 3.0 \\
India & 3.8 & 20.4 \\
Indonesia & 23.2 & 39.4 \\
Korea & 23.7 & 22.9 \\
Malaysia & 10.5 & 36.4 \\
Pakistan & .678 & 11.2 \\
Philippines & 2.1 & 14.94 \\
Sri Lanka & .04 & 5.02 \\
Thailand & 37.7 & 54.4 \\
Jordan & .015 & 1.6 \\
South Africa & 2.2 & 9.5 \\
Turkey & 2.1 & 8.4 \\
Zimbabwe & .001 & .10 \\
Poland & .140 & 1.5 \\
Czech Republic & .981 & 8.62 \\
Hungary & 1.1 & 10.2 \\
Singapore & 65.0 & 30.8 \\
China & 18.7 & 32.3 \\
Taiwan & 3.0 & 11.9 \\
\hline
\end{tabular}

Source: Bank of International Settlements

Summary Statistics: Asian Crisis 1997-1998

\begin{tabular}{|l|c|c|}
\hline Variable & Mean & Standard Deviation \\
\hline Lending Boom & 11.402 & 65.431 \\
Real Appreciation & -1.325 & 6.991 \\
Current Account & -2.273 & 4.456 \\
Budget & -1.567 & 4.579 \\
M2/ Reserve & 7.319 & 10.223 \\
Capital Inflows & 4.089 & 4.106 \\
Short-term flows & 1.543 & 5.278 \\
\hline
\end{tabular}




\section{Appendix B : Data}

This Appendix describes the construction of the data. Most of the data come from IMF's International Financial Statistics. Taiwanese data are from the Financial Statistics (IMF) of Central Bank of China (www.cbc.gov.tw) and from various issues of Monthly Bulletin of Statistics of the Republic of China.

\section{Real Exchange Rate Appreciation:}

As in Glick and Rose (1999), the real exchange rate appreciation was calculated as the percentage change in the real exchange rate between the average of the three previous years and the crisis year. Most of the real exchange rate data are from J.P. Morgan \& Co. The data for Jordan, Hungary, Checzh Republic, Sri Lanka, Zimbabwe, Poland, and China were not available from J.P. Morgan \& Co. We calculated the real exchange rates for these countries as the weighted sum of the bilateral real exchange rates (using CPI's) with respect to the Dollar, Yen, and DM. Average nominal exchange rates and CPI data for this purpose were obtained from IMF's International Financial Statistics.

\section{Lending Boom:}

First, we got the ratio of the claims on the private sector of the deposit money banks (IFS line 32d) to nominal GDP (IFS line 99b). We then used the growth rate of this ratio between 1992 and 1996.

\section{Current Account:}

The current account (IFS line 78al) has been converted to national currency using the annual average exchange rate (IFS line rf). We used the converted current account in 1996 as a percentage of 1996 GDP. A positive sign on this variable denotes current account surplus, while a negative sign denotes a current account deficit.

\section{Budget:}

The variable Budget is constructed as government budget (IFS line 80) as a percentage of nominal GDP. A budget surplus shows a positive sign, and deficit shows a negative sign. We then used the ratio of 1996.

\section{M2 / Reserves:}

We converted total reserves minus gold (IFS line 11) to national currency, using average exchange rate. We calculated M2 as the sum of money (IFS line 34) and quasi money (IFS line 35). The ratio of M2 to total reserve (minus gold) of 1996 was used as a reserve adequacy for the Asian crisis.

\section{Capital Inflow:}

We constructed this variable by summing the capital account (IFS line 78bc), the financial account (IFS line 78bj), and net errors and omissions (IFS 78ca), then the sum was converted to national currency by multiplying it with annual average exchange rate; then we obtained a ratio of that converted sum to nominal GDP. Share of Capital inflows to GDP of 1996 were used in this study.

Short-term Capital Inflows:

The source for this variable is the IMF's Balance of Payments Statistics. This variable is con- 
structed by summing portfolio investment (line 4600), errors and omissions (line 4998), and other short-term flows within the category of "other investments"(line 4727, 4733, 4734, 4768, 4777, 4789, and 4792). Share of Short-term Capital Inflows to GDP of 1996 were used. 